\title{
Healthy and Quality Urban Spaces for Sustainable Development of Heritage Sites
}

\author{
Arzu Çahantimur ${ }^{1}$, Assoc.Prof. , Ph.D. \\ Rengin Beceren Öztürk ${ }^{2}$, Asst.Prof., Ph. D., \\ Burcu Hemitli Erkan ${ }^{3}$, M. Arch.
}

\begin{abstract}
This study investigates the ways how urban public spaces that have historical and cultural heritage values can take part within sustainable development process of cities by providing healthy and quality spaces for everyday life. Following the first part which includes literature analysis, the second part explains the reasons for selection of the case study area where the evaluations will carried out. The case study area of the project is defined as the open public spaces between the historical housing area "Hisar District" and the trade center "Historical Covered Bazaar and Hans District" which created historical city center of Bursa that has a valuable historical and cultural heritage. In the third part, important features of the case study area together with their potentials and problems are identified. The study ends up with opinions and suggestions about providing healthy and quality urban environments for the case study area.
\end{abstract}

Key words: cultural heritage, environmental quality, healthy-city, historic city, sustainable urban development, urban design, Bursa, Turkey

\section{Introduction}

Urban areas, where about two-third of the population in developed and developing countries live, unfortunately provide an unhealthy environment for the society. Cities that are mostly characterized by heavy traffic, pollution, noise, violence and social isolation do not possess healthy and quality public spaces. In recent years, however, local authorities increasingly became aware of the fact that they could initiate a sustainable development process by increasing the quality of life of the urban population and providing people a healthy environment. In particular, the administrators of the cities that are member to the World Health Organization European Healthy Cities Network, by accepting that urban planning and urban planning activities should be based on the concepts of "health" and "healthy city," continue their efforts in that direction (WHO, 2009).

All interested parties acknowledge that cities should possess quality and attractive urban open spaces that are one of the significant indicators of a healthy city and every urbanite should have access to quality urban activities. However, the fact that instead of considering the problems such as urban sprawl, housing and infrastructure that particularly have an adverse impact on historical environment in urban design scale, consideration of these issues in the individual building and monument scale resulted in the inadequacy of the studies in meeting the healthy public space needs of the urbanites. On the other hand, community relations, which constantly change and advance, cause

${ }^{1}$ Assoc.Prof., Ph. D., Uludağ University, Faculty of Architecture, Turkey

${ }^{2}$ Asst.Prof., Ph. D., Uludağ University, Faculty of Architecture, Turkey.

${ }^{3}$ M. Arch. 
the redefinition and reproduction of the urban texture. The uses that construct the historic urban texture were developed to meet the social and economic needs of their own period. Changing lifestyles, government structure, increased capital power, population growth and migrations have led to the creation of different living spaces along with the introduction of different demands. In this process of change and development, the environmental and living quality of historical urban environments should be improved to sustain the requirements of the contemporary life and prevent these from turning into depression areas. Thus, it is necessary to produce solutions that would bridge the past and the future, protect the unique identities of the historical cities, and consider the balance between preservation and development. If the issue is addressed within the urban design scale, the above mentioned suggestions could succeed. It is necessary to assess the urban design act as a part of the whole environmental systems to investigate the criteria that would enable sustainability of the urban environment with its historical and cultural heritage and sustainability of the whole city. Thus, it could be ensured that historical urban environments would be spaces where the population could spend better and healthier lives and the needs of future generations are provided for.

In this context, the present study examined how the urban areas with historical and cultural heritage would be able to function within sustainable development dynamics by providing healthy and quality living spaces. The issue was addressed in the scale of "urban design" discipline, of which main objective is to meet the needs for a healthy urban space. After the first section that includes a literature review of theoretical and empirical studies on the subject, the second section includes the introduction of the sample area that would be assessed and the reasons for the selection of this particular area. Open public spaces between the residential area "Hisar District" and the commercial area "Historical Covered Bazaar and Hans District", which constitute the historical Bursa city center ${ }^{1}$ that contains a valuable historical and cultural heritage were determined as the area where the field study would be conducted in the present study. In the third section, these urban spaces were examined. The characteristics and opportunities and problems in these spaces were determined. The study concluded by presenting views and recommendations on the implementation of procedures that would provide healthy and high quality urban spaces.

\section{Urban Design Concept And Its Significance For Healthy And Sustainable Cit1es}

The factors that distinguish a city are its environment and history. The historical environment is a physical environment that people construct over time and provides a foundation for the cultural urban identity by conveying the accumulations of history to the future city. In the 21st century, people started to migrate to cities and cities started to grow. As the cities grew, urban sprawl, housing and infrastructural problems negatively

1 Bursa was included in the UNESCO World Heritage list in 2014 June with the nomination file titled as "Bursa and Cumallkazlk: the Birth of the Ottoman Empire". 
affected historical environment in particular and most of the preservation works were limited to single building and monument scale. Population growth and migration led to a rapid increase in unhealthy environments that are poorly built. One of the most important current urban problems is the decrease in the integrity, the clarity and the value of historical environments that have a significant role in the life and sustainability of cities due to the uncontrolled construction in or around these environments.

The fact that initial studies conducted in historical urban centers in Turkey were limited to monumental architectural works, and further projects that are attempted to be implemented only on certain focal points were limited to "single building scale" became a threat to historical urban environments. Consideration of urban spaces in the context of open space design rather than its relations with the environment can result in its disconnection with the whole city and in an increase in the number of unhealthy urban spaces.

The health and quality of historical urban spaces should be the main objective. In particular, the administrators of the cities that are member to the World Health Organization European Healthy Cities Network, by accepting that urban planning and urban planning activities should be based on the concepts of "health" and "healthy city," continue their efforts in that direction. To create environments that would protect and support the members, the Network aims to provide a physical and built environment that enables and supports healthy living, peaceful and safe recreation, social interaction, accessibility and mobility (WHO,2005). The work conducted between 2009 and 2013, which was the 5th phase of the Healthy Cities Network's work, was remarkable in terms of integrating healthy urban components into urban design processes and projects, and prioritizing capacity building efforts to achieve success in practice (WHO,2009).

When the topic is addressed in the context of studies that aimed at creating a healthy and quality environment for urban spaces in historical city centers, different methods are required. The main decisions and strategies that would be adopted in upper scales should be used effectively at every stage to ensure that the original values of historical and cultural heritage spaces are transferred to future generations without deterioration of their unique values and to maintain their sustainability in connection with the whole city. Sustainable urban development criteria should be assessed in the context of the relationship of these areas to the city as a whole, and work should be conducted to realize sustainable urban development (Çahantimur and Turgut Y1ldız, 2008).

The concept of Urban Design, which is prominent in the process of creating sustainable and healthy cities, emerged as a result of the insufficiency of urban spaces in built environment and their need for renewal and failure of the architecture and urban planning disciplines in preservation and enrichment of historical heritage. The discipline of urban design is significant in fulfilling the social requirements in urban space (Rodwell, 2008).

The word urban in "urban design" is defined as "in, relating to or characteristic of a town or a city" (Oxford Dictionary). The word design is defined as "the art or action of conceiving of and producing a plan or drawing of something before it is made" or "the arrangement of the features of an artifact, as produced from following a plan or drawing" (Oxford Dictionary). It could be considered that the word urban in urban design is the product that emerges as the result of the relationship between the urban 
space and the urbanite, and the design is the related process. In order to determine the scope of urban design, it is necessary to determine its fundamental elements, what these should be, what / where constitutes the study area (scale) of the urban design, and who should participate in this process. While designing urban spaces that are important for ensuring the health and sustainability of the historic urban environment, a process should be conducted with the involvement of the entire community and all related disciplines.

A famous urban planner and academician Tekeli(2011) states, preservation work that were developed by considering a single or individual building, but not its environment and significance within the city are inadequate in historical urban areas. The insufficiency of this approach, which is not consistent with the fact that the urban services and public spaces should serve all urbanites, which is among the criteria of healthy cities, demonstrates the significance of urban design, which is an interdisciplinary approach.

Adopted by the decision of the High Planning Council dated 25.10.2010 no. 2010/34, the council of KENTGES Integrated Urban Development Strategy and Action Plan, prepared by the Ministry of Environment and Urban Planning, determined that urban design should be within the hierarchy of national planning. Thus, "Urban Design" that integrates planning and architecture is required to take its place in the national planning system (Ministry of Public Works, 2009).The Strategic Objective in Bursa Metropolitan Municipality 2010-2014 Strategic Plan detailed the significance and indicative nature of urban design in healthy, high quality historical urban spaces in Articles 3.1, 11.1 and $11.2^{2}$.

There have been many interdisciplinary studies and NGOs of urban design all around the world since 2000s. One of them is the Urban Design Protocol for Australian Cities, constructed in 2011. It emphasizes the importance of urban design for developing and growing cities. The protocol established the foundations and principles of urban design that could serve as a guide for designers. According to this protocol, a quality urban design is a combination of productive, sustainable and habitable spaces for urbanites and excellence in management and design (http://www.urbandesign.gov.au). (Figure 1,2).

${ }^{2}$ Focus Area 3: Preservation of Historical and Cultural Heritage

Strategic Objective 3.1: To improve the perception of the historical identity of the bistorical city of Bursa, to integrate the urban bistorical and cultural heritage with contemporary life for conveyance to future generations ( $p .51)$.

Focus Area 11: Development and Planning

Strategic Objective 11.1: To create a planned, healtby and safe city suitable for sustainable environmental conditions and in harmony with historical and natural environment.

Strategic Objective 11.2: Rehabilitation of depressed spaces or areas of urban sprawl with the Urban Plan Action Plans, construction of a sustainable environment, ecological settlements, specialized cities, corridor rehabilitation and special urban spaces based on the socio-economic structure, establishment of metropolitan area prestige backbones, safe andcreating sustainable living spaces (p.62). 


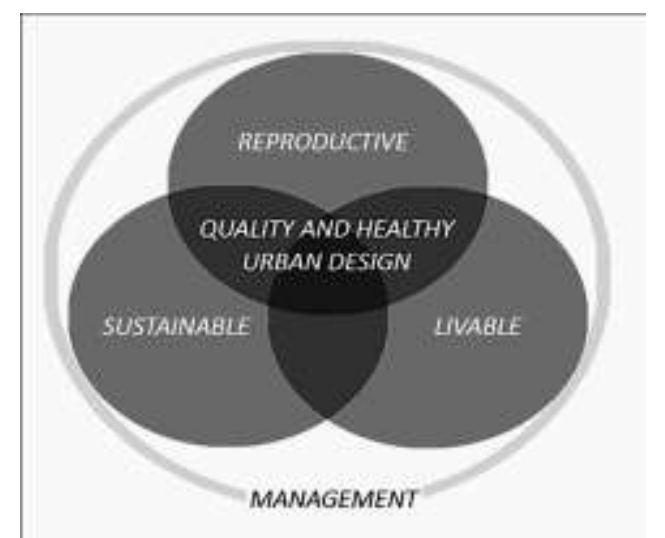

Figure 1. Quality Urban Spaces

\begin{tabular}{|l|c|c|c|c|c|}
\hline $\begin{array}{l}\text { URBAN } \\
\text { PLACE } \\
\text { (product) }\end{array}$ & $\begin{array}{l}\text { URBAN SPACE: } \\
\text { PRODUCTIVITY } \\
\text { SUSTAINABILITY }\end{array}$ & $\begin{array}{c}\text { Enhancing } \\
\text { LEOPLE: }\end{array}$ & Connected & Diverse & Enduring \\
\cline { 2 - 6 } & Healthy & Vibrant & Safe & Walkable \\
\hline $\begin{array}{l}\text { DESICN } \\
\text { (process) }\end{array}$ & LEADERSHIP & $\begin{array}{c}\text { Planning } \\
\text { Context }\end{array}$ & Engagement & $\begin{array}{l}\text { Success } \\
\text { Product }\end{array}$ & Monitoring \\
\hline
\end{tabular}

Figure 2. Components of Quality Urban Place and Design

Urban design is a discipline that emerged for the maintenance and sustainability of a healthy and quality urban space, and it a right for the urbanite. The sustained debate since the emergence of the urban design concept was related to how urban design and the principles of a quality urban space should be created and developed.

\section{Case Study: Bursa - Hisar District}

Hisar district is located within the borders of the Osmangazi county in Bursa, Turkey (Figure 3). This traditional area contains many historical and cultural heritage monuments and civil architecture works since it is located where Bursa was initially settled. Hisar district was surrounded by the walls that were built during the Bithynian period and until the Ottomans conquered Bursa, the city was a fortified city within a fortress $^{3}$. Within the Ottoman Empire, the city became the capital of the state and an administration center until 1402 (Maydaer, 2009). The Hisar district did not loose its characteristic as the residential area for prominent people and administrators of the city until today. Today, it contains a building inventory that is significant for Bursa but not utilized productively in its entirety (Çahantimur, 2007). (Figure 4)

\footnotetext{
${ }^{3}$ Fotress means 'Hisar' in Turkish.
} 


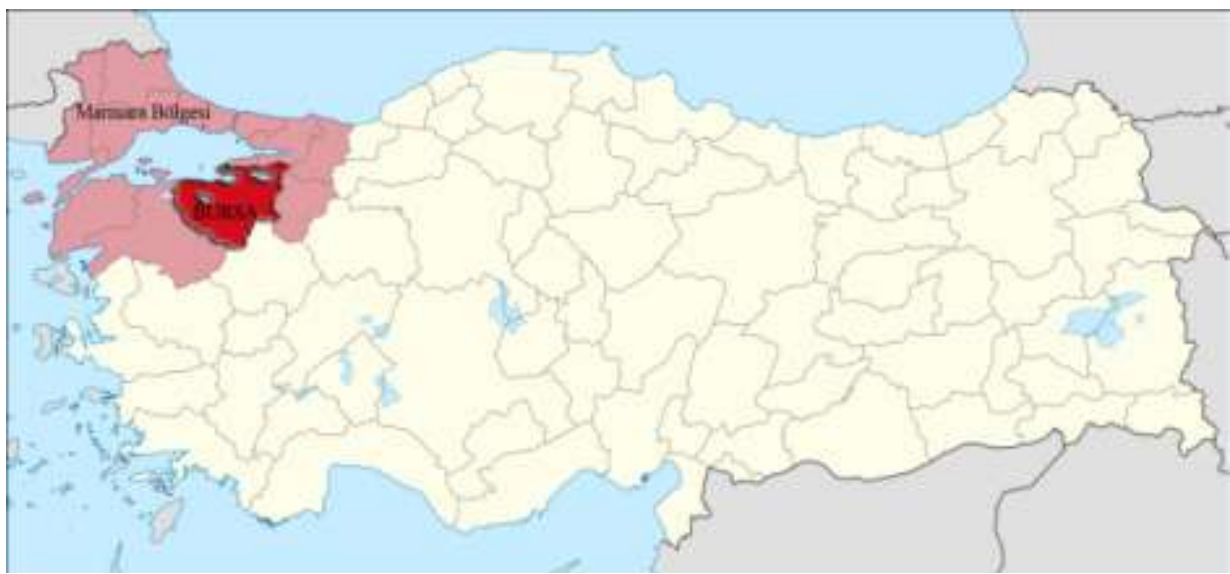

Figure 3. Bursa in Turkey and Marmara Region

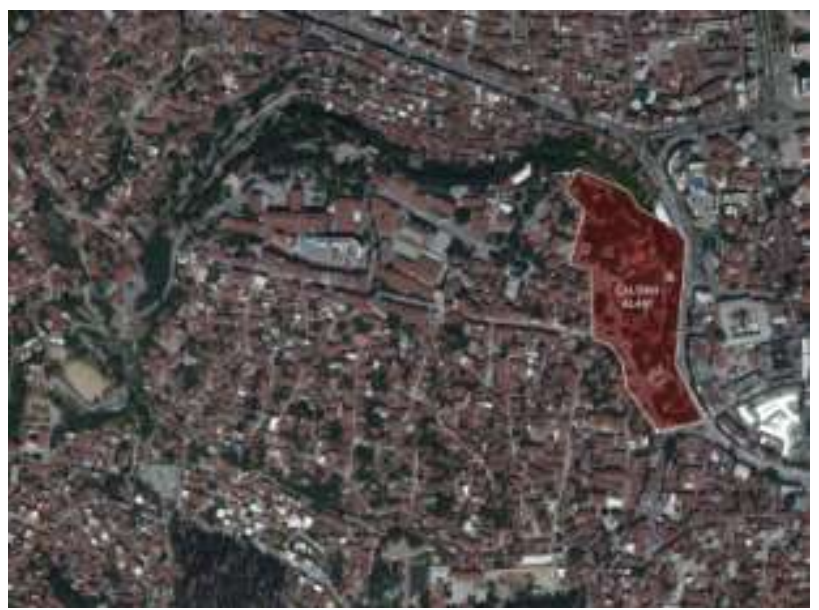

Figure 4. Case Study Area in Hisar District in Bursa (adapted from Google Earth)

Due to its historical and cultural heritage values, the area between Hisar and the Historic Covered Bazaar and Hans District was designated as the study area (Figure 5). Urban public spaces between these two districts, which are of great significance for Bursa historical city center, were examined from the perspective of the urban design discipline and important features of urban spaces with their existing historical and cultural values and the potential of and problems in these areas were identified. The present study aims to contribute to the construction of healthy and quality spaces that would sustain the urban cultural heritage that contributes to the life of the urbanite, which should be enriched with new participations, meanings and developments.

In this context, the physical, spatial and socio-cultural characteristics of the area were identified via physical analysis, observations and surveys. Then these characteristics were evaluated in the context of the criteria of healthy and quality urban spaces. Proposals were developed for the improvement of the case study area by preserving its significance and value. Another important objective was to include public spaces where every inhabitant of Bursa and Hisar could access healthy and quality urban activities. 


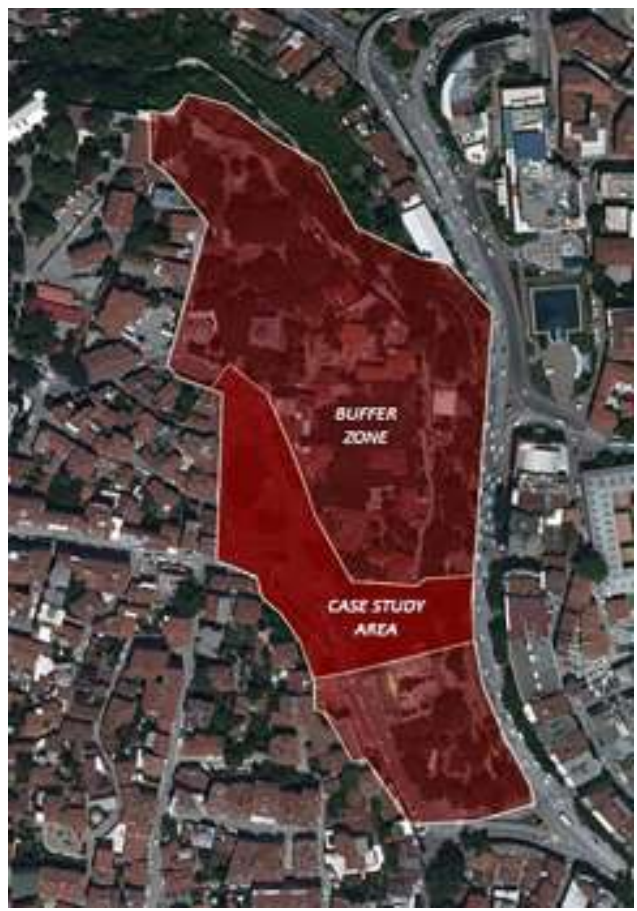

Figure 5. Boundaries of Case Study Area (adapted from Google Earth)

\section{Proposals For Healthy And Quality Urban Spaces In Hisar District}

Within the scope of this study, a method proposal is developed in order to provide a road map that would shed light on urban design projects, which would be conducted in historical areas. The method, scrutinized with the case study area, included three stages. In the first stage, the spaces, from the general scale to the individual scale, that were affected by urban design and its study disciplines are presented in the table shown in Figure 6. As Doxiadis (1968) states in his famous work Ekistics: An Introduction to the Science of Human Settlements, it is easy to create urban spaces at the determined locations on the urban scale, but only through urban design, it is possible to create a whole that contains parts, which are usable and modern at the same time for the whole city. In designing urban spaces on the smallest scale, its effects on the whole city should be considered, vice versa, when designing urban spaces on the upper scale, the spaces and people living in and around the smallest scale affected by them should also be considered.

The second step of the proposed method involves the examination of these urban spaces from the perspective of the urban design discipline. Spatial and social analysis that would be conducted within this scope would be used to determine the significant properties and the potentials and problems of the spaces.

In the third stage, assessments about urban design features that would be used to construct quality and healthy public spaces, of which required components are productivity, sustainability and livability as presented in Figure 1. The data obtained from 
the assessments are evaluated to develop proposals of improving urban design projects for the case study area.

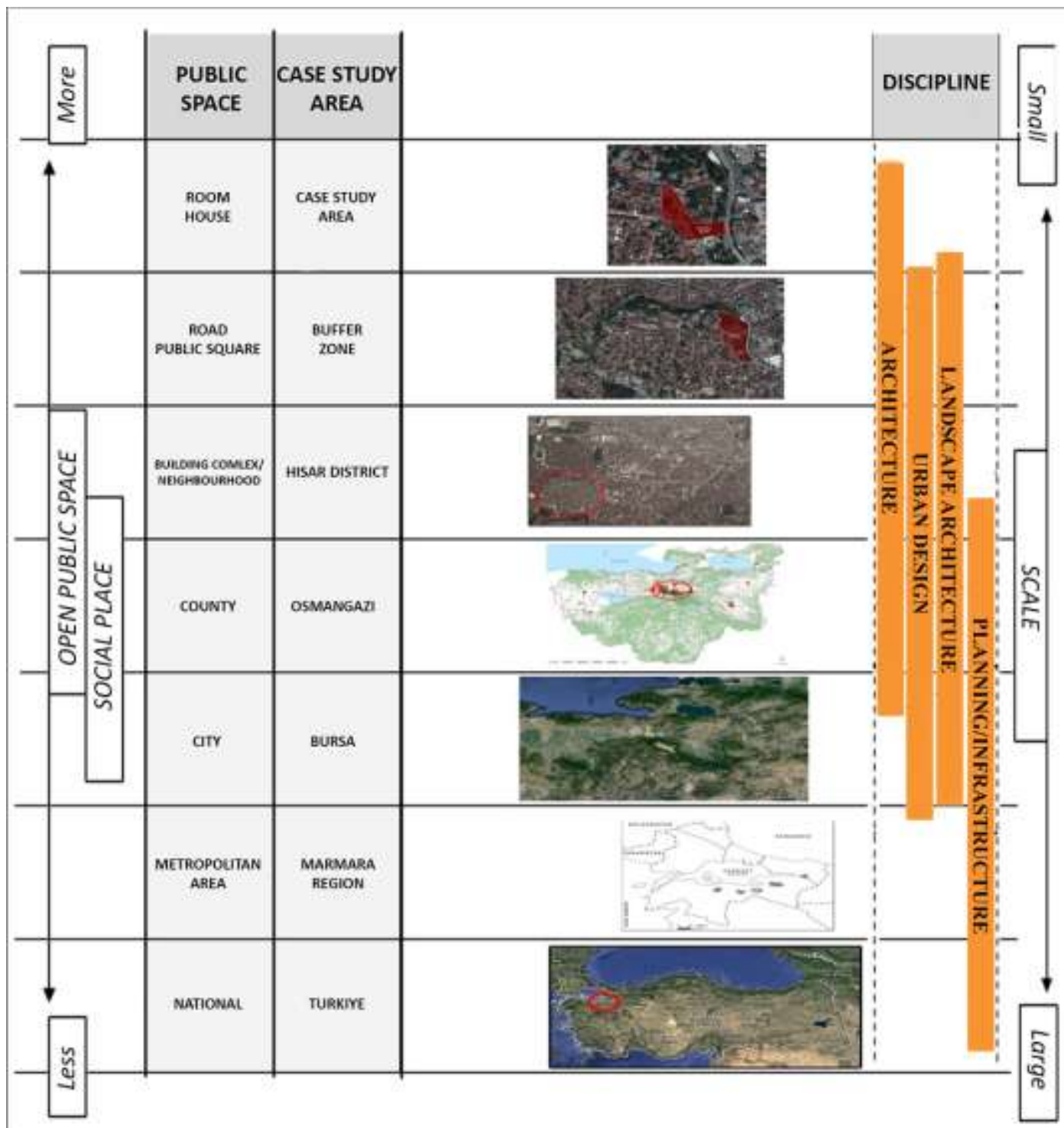

Figure 6. Urban Design Scale and Scope for the Case Study Area

At the end of the physical analysis conducted in the selected study area, the properties of the area are determined and evaluated in the context of the criteria that are required to provide healthy and quality urban public spaces. The data obtained as a result of the observation, participatory observation, physical environment analysis, archive analysis studies could be interpreted as follows. 
Unqualified and neglected buildings, inadequate indoor and outdoor public spaces around the study area are insufficient to meet the needs of the inhabitants, workers, tourists and transit passengers. This district is not used effectively due to insecure areas and this insecurity poses a threat to the items of historical and cultural heritage (Figure 7). The security of the area should be provided and activities related to the historical and cultural characteristics of the area should be organized. Thus, urban spaces that provide opportunities for people and urbanites to develop their own local economy, environment and social values would be created.

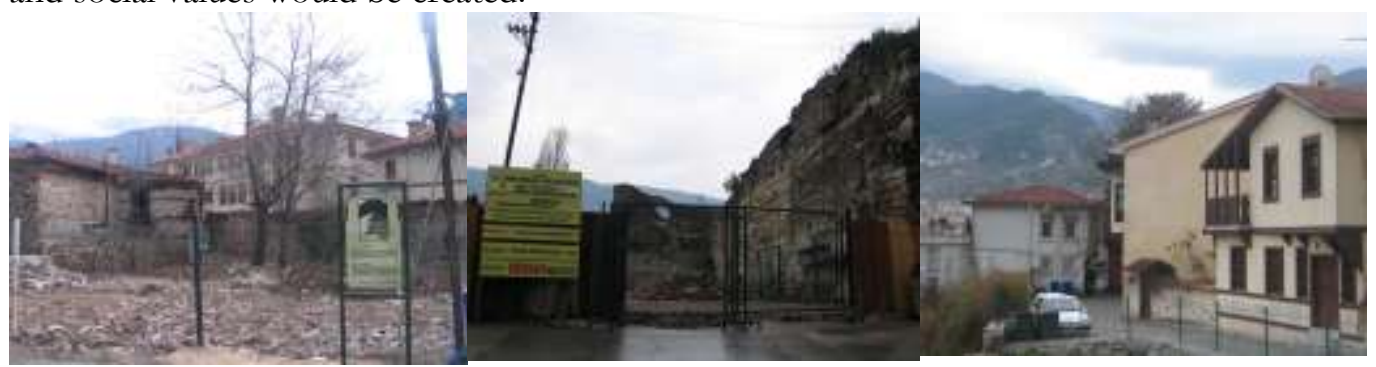

Figure 7. Some views from case study area

The urban spaces in the study area do not fit into a physical and social context. Traffic is jammed, pavements are insufficient and maintained poorly, parking problems are serious. In an environment that is not supported by a perceptually and functionally comprehensible transportation system, users are often unable to perceive where they are and where they should go (Figure 8). Unfortunately, the area has no connection with its past and its social and cultural heritage. The historical heritage awareness of the inhabitants should be kept alive and urban spaces that would covey this awareness to future generations should be constructed. An accessibility plan that is associated with the natural and historical environment and could be easily used by everyone should be designed.
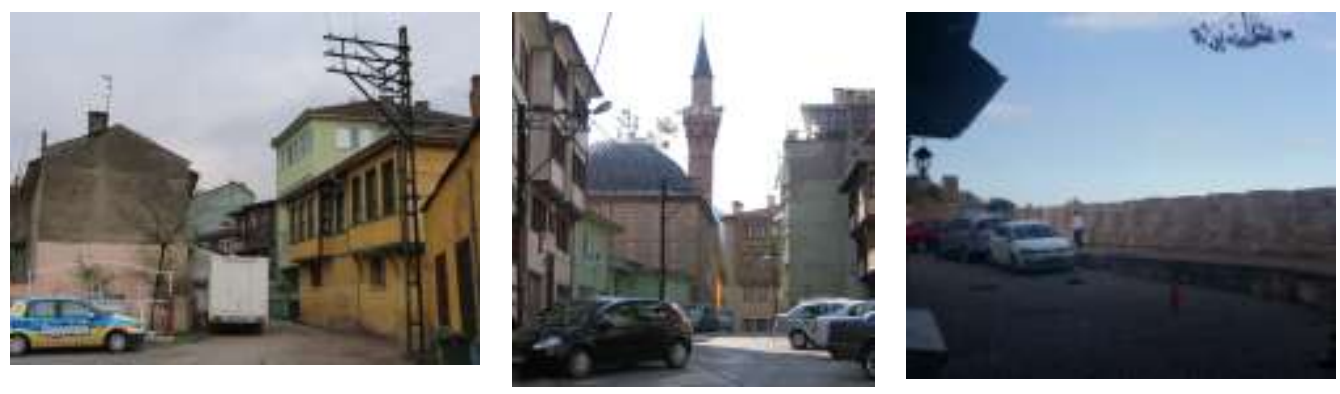

Figure 8. Some views from case study area

The study area does not include adequate social / public spaces in the context of urban space diversity. Diversity must be provided to meet the needs of different individuals. These urban spaces should create routes where different experiences could be experienced in harmony despite their diversity. 
The area is neither known sufficiently nor utilized effectively by the urbanites or the tourists. The historical and cultural heritage in the area does not attract the attention it deserved. This situation increases the threat of extinction for historical and cultural heritage sites. Studies should be conducted to increase the perceptibility of the historical identity of the area and to ensure the continuity of the urban spaces that are used by the urbanites for their daily needs and to convey these spaces to future generations ${ }^{4}$.

Urban spaces in the study area don't provide sufficient livability for local individuals, small business owners and tourists alike. There are almost no comfortable, outdoor and indoor public spaces where the urbanites would feel free and a part of, where they could walk and relax. Existing open spaces are not preferred by people. These areas are not considered as habitable by the urbanites since they do not possess accessibility, reliability, vitality and health elements. The results of the analysis are summarized in Figure 9.

4 The outcomes of the analysis are supported by the outcomes of the strategy development workshops organized in the scope of scientific research Project titled as "Site Management Plan of Bursa Osmangazi County/Hisar Region "which was undertaken by Uludă̆ University and Bursa Metropolitan Municipality Protocol, Coordinator: Assoc. Prof. Ph.D., Arzu Ispalar Cabantimur. 


\begin{tabular}{|c|c|c|c|}
\hline & Public & Tradesman & Tourist \\
\hline$\frac{\frac{\pi}{\pi}}{\frac{1}{0}}$ & $\begin{array}{l}\text { public spaces are insuffici } \\
\text { ent and inadequate for } \\
\text { local people. Quality } \\
\text { public spaces for cultural } \\
\text { activities and social needs } \\
\text { should be developed. }\end{array}$ & $\begin{array}{l}\text { Safety and security } \\
\text { problems don't let to } \\
\text { improve new business } \\
\text { opportunities. } \\
\text { Local economy should be } \\
\text { developed via providing } \\
\text { safe and secure public } \\
\text { spaces. }\end{array}$ & $\begin{array}{l}\text { public spaces are } \\
\text { insufficient for tourists' } \\
\text { needs. Accommodation } \\
\text { alternatives are poor. } \\
\text { Quality accommodation } \\
\text { alternatives and public } \\
\text { spaces for daily activities } \\
\text { should be offered. }\end{array}$ \\
\hline 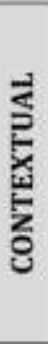 & $\begin{array}{l}\text { Links with the social and } \\
\text { cultural heritage values } \\
\text { are weak. Public spaces } \\
\text { should be developed in } \\
\text { order to retain collective } \\
\text { memory. }\end{array}$ & $\begin{array}{l}\text { Transformation } \\
\text { alternatives are } \\
\text { insufficient. Accessibility } \\
\text { is weak. Cultural heritage } \\
\text { values are not known } \\
\text { good enough. The area } \\
\text { should be more } \\
\text { recognizable and } \\
\text { accessible. }\end{array}$ & $\begin{array}{l}\text { There aren't enough } \\
\text { information about the } \\
\text { history and culture of the } \\
\text { area. The pedestrian } \\
\text { activities are insufficient } \\
\text { Guided historic tours } \\
\text { should be offered. }\end{array}$ \\
\hline$\frac{2}{\overline{0}}$ & $\begin{array}{l}\text { public spaces are insuffici } \\
\text { ent and inadequate for } \\
\text { local people. New public } \\
\text { places with different } \\
\text { kinds of activities should } \\
\text { be provided in order to } \\
\text { increase the vitality. }\end{array}$ & $\begin{array}{l}\text { Only some eating facilities } \\
\text { and some small shopping } \\
\text { units exist. Alternatives of } \\
\text { different functions and } \\
\text { businesses should be } \\
\text { developed via increasing } \\
\text { touristic activities. }\end{array}$ & \multirow{2}{*}{$\begin{array}{l}\text { Presentation of the } \\
\text { heritage values of the } \\
\text { area to the city dwellers } \\
\text { and tourists via local and } \\
\text { central governments' } \\
\text { tourism strategies is vital. } \\
\text { A tourism management } \\
\text { plan should be developed. } \\
\text { The area should be a part } \\
\text { of heritage tourism routes } \\
\text { of the country. The area } \\
\text { should be conserved and } \\
\text { developed together with } \\
\text { its local people. }\end{array}$} \\
\hline$\frac{Z}{3}$ & $\begin{array}{l}\text { Heritage conservation } \\
\text { consciousness is missing. } \\
\text { People should be aware of } \\
\text { the importance of their } \\
\text { living area for the cultural } \\
\text { heritage of the city and } \\
\text { the country. Some } \\
\text { education programs } \\
\text { should be developed. }\end{array}$ & $\begin{array}{l}\text { Presentation of the } \\
\text { historic importance of the } \\
\text { area to the local people } \\
\text { and tourists is vital for } \\
\text { the continuity and } \\
\text { development of the small } \\
\text { businesses around. }\end{array}$ & \\
\hline & & & NABILITY \\
\hline
\end{tabular}

Figure 9. Outcomes of the analysis

\section{Conclusion}

As a result of the determinative studies, it was revealed that the historical and cultural heritage in the area between the historical trade district Hanlar Quarter and the historical residential neighborhood of the Hisar Quarter is not known sufficiently by urbanites as well as the tourists and did not receive the attention it deserved. If urban spaces with productive and sustainable qualities that would keep the historical heritage of the area alive would be developed and the problems in the area are resolved, it was observed that all users would want to spend time in Hisar District. Public spaces in and 
around the study area should possess elements that would develop environmental and social values for all users, associated with the social and cultural experiences of the city, with diversity that would meet the needs of all users, and sustain the urban spaces for the use of future generations.

It was observed that it is important to provide healthy urban spaces to improve their vitality, safety and accessibility and to ensure that the historical urban center is livable for the urbanites, small business owners and tourists. As summarized in figure 9, it was observed that the development of livable urban spaces with productive and sustainable qualities is necessary for the quality and health of the historical cultural heritage area and to increase the level of use.

As a result of the assessments conducted specifically on the study area, it was observed that different methods are required in studies that aim to create a healthy and quality environment in public spaces at historical urban centers. In the environment of rapid change and development experienced in cities, it is necessary to increase the quality of life of historical urban environments to meet current needs and prevent these areas to become depressed. Thus, it is necessary to provide solutions that combine the past and the future, preserve the urban identity and aim preservation - development - renovation. Unhealthy urban spaces can be transformed into healthy and quality spaces and could be preserved thanks to urban design. The slightest intervention on the urban environments affects individuals' relationships with urban space and identity values. Urban design would guide towards spaces that preserve urban environment with healthy and quality urban spaces and historical heritage values and provide the most healthy living conditions for the urbanites with a productive, sustainable and livable approach.

\section{References}

Çahantimur, A.I., Yıldız, H.T., "Sürdürülebilir Kentsel Gelişmeye Sosyo-kültürel Bir Yaklaşım: Bursa Örneği", (A Socio-cultural approach for Sustainable Urban Development: Bursa as a Case) İTÜ Journal, Volume 7/2, pp. 3-13, 2008.

Çahantimur, A.I., "Bursa Hisar Bölgesinin Kentsel Gelişiminin Değerlendirilmesi”, (Evaluation of Urban Development of Bursa, Hisar Region) Bursa'nın Kentsel ve Mimari Gelişimi Sempozyumu, Bursa, 2007.

Çahantimur, A.I., "Bursa Osmangazi İlçesi/Hisar Bölgesi Yönetim Planı" (Site Management Plan of Bursa Osmangazi County/Hisar Region) unpublished scientific research project undertaken by Uludağ University and Bursa Metropolitan Municipality Protocol, Coordinator: Assoc. Prof. Ph.D., Arzu Ispalar Çahantimur, 2013.

Doxiadis, C.A, Ekistics: An Introduction to the Science of Human Settlements, Oxford University Press, 1968.

Maydaer, S. "Osmanlı Klasik Döneminde Bursa'da Bir Semt Hisar", ( Hisar; A Region in Bursa in Classical Period of the Ottoman Empire) Emin Yayınlar1, 2009.

Rodwell, D., Conversation and Sustainability in Historic Cities, Blackwell Publishing, 2007.

Tekeli, I.., “Tasarım, Mimarlık ve Mimarlar", (Design, Architecture and Architects) Tarih Vakfi Yurt Yayınları , 2011.

Turkish Republic Ministry of Environment and Urban Planning, KENTGES-Kentsel Gelişim Stratejiler Raporu, (Report of Urban Development Strategies), Ankara, 2009.

World Health Organization, The World Health Report, Switzerland, 2005.

World Health Organization, Phase V (2009-2013) of the WHO European Healthy Cities Network: Goals and Requirements, Denmark, 2009.

http://www.urbandesign.gov.au 